\title{
"Let me have my untrammeled growth" Gender, Education, and The Colonized Intellectual in Nervous Conditions
}

Dustin C. Rozier

Portland State University

Follow this and additional works at: https://pdxscholar.library.pdx.edu/mcnair Let us know how access to this document benefits you.

\section{Recommended Citation}

Rozier, Dustin C. (2019) "'Let me have my untrammeled growth" Gender, Education, and The Colonized Intellectual in Nervous Conditions," PSU McNair Scholars Online Journal: Vol. 13: Iss. 1, Article 7. https://doi.org/10.15760/mcnair.2019.13.1.7 
"Let me have my untrammeled growth"

Gender, Education, and The Colonized Intellectual in Nervous Conditions

"This business of womanhood is a heavy burden,"” are the words told to Tambu in Tsitsi Dangarembga's novel Nervous Conditions which portrays the struggles of the colonized in a modern era through a young woman and the perils of her attempt to rise above her stratum in poverty through the only outlet made available: education (Dangarembga 15). In the colonized state of former Rhodesia, Tambu has firsthand experience of this through her Uncle Babamukuru who was able to not only receive an education as an adolescent, but continue on to a higher degree in Britain. This allowed him to carve out a life for himself and his immediate family while also providing opportunities for his extended family. The trials faced along the way are hazardous: through her education Tambu not only recognizes the conflicted states between her cousin, Nyasha, and her Uncle Babamukuru, but the ways education and its freedom can be wielded in devastating acts of oppression by the colonized state.

As the epigraph of the novel says, "The condition of native is a nervous condition", and comes from the preface to Frantz Fanon's The Wretched of the Earth, which also influenced the title of the novel. Tambu, Nyasha, and Babamukuru depict this "nervous condition" through the stages of their intellectual growth, as these characters become manifestations of the mental states Fanon describes in their path to employ Westernized education in the development of their own culture. This colonial education is used to impede and administer control, instead of liberating and offering more avenues of discourse, thought, and treatment outside of oppressive systems; whether these systems exist within the framework of the colonized state or the traditional culture. 
Fanon describes the growth of the colonized intellectual in three stages, beginning with their journey to a state where they are fully versed in the education and knowledge of the colonizer and think outside of their nationality in a Western sense. Then, they begin to recognize a lack of relation to their own tradition and culture, which causes them to reflect back to both their personal and people's history to re-establish this connection. The final stage is characterized by an understanding of what must be done for their people, causing their work to take on a more revolutionary form in attempts to inspire their citizens (158-9). Each of these stages corresponds to the three main characters of the text, as Babamukuru portrays the first stage, Nyasha the second and Tambu the influential and teleological third stage.

As this novel is set during the late years of colonial rule in Rhodesia, the novel portrays three characters struggling to find their place within, and beyond, these colonial education systems. Tambu follow an inverted route of the colonized intellectual that Fanon describes by arising from peasant roots, therefore bringing this experience into her quest for freedom. Fanon later says in his conclusion about the growth of the colonized intellectual, "Now, comrades, now is the time to decide to change sides. We must shake off the great mantle of night which has enveloped us, and reach for the light" (235). This night includes those oppressive tendencies towards women characterized by both Western and traditional cultures, and that light must be a place where equality between the sexes flourishes. Women must have the opportunities to do things for their culture just like men, to step beyond and become more than both their cultures and the colonizers allow. 
Education is a means to rise in colonized society, but it is controlled by the colonizer and only rewarded when the colonized relinquish consent to the colonizer's position of granting this opportunity, and as Jean-Paul Sartre says in the preface to The Wretched of the Earth: "The status of 'native' is a neurosis introduced and maintained by the colonist in the colonized with their consent" (liv). As Tambu's grandmother and Babamukuru's mother describes the story of his education, it comes from the hands of the "holy wizards", or the white men which offered a place for Babamukuru at their mission to work and learn (28-9). Tambu's grandmother coined this fantastical term, which is significant not only due to the way it shrouds the colonizer's identity, but its relation to Tambu via their native language, Shona, and how it acts as an oral medium for their history to be shared. As Tambu's grandmother relates the story of their family, she describes both how the colonizer takes away opportunities, "The white wizard had no use for women and children. He threw my grandmother and her children off the farm" and grants them, "They [holy wizards] set him [Babamukuru] to work in their farm by day. By night he was educated in their wizardry. For my grandmother, being sagacious and having foresight, had begged them to prepare him for life in their world" (28-9). This displays how their family was saved by both the grandmother and Babamukuru's tenaciousness, yet also their consent to the colonizers as Babamukuru's indoctrination slowly occurred at the mission (29). Tambu's grandmother gave consent when needed, but by telling this story to Tambu she also combats the colonizer's power and informs Tambu of the ploys used to convince natives to adhere to the colonizer's control.

In contrast to the fantastical element created by using the term "wizards", the very real-world effects that the colonizer has over the colonized is prevalent. Their uncle, 
Babamukuru, is held as the elite of their family, due to his commitment to his studies that lead him to become the headmaster of the mission school after receiving a graduate degree in England. His wife, Maiguru, also received her degree, but receives little respect for doing so, while Tambu's cousins Nyasha and Chido accompanied them to England, and this played a huge role in the development of the children's personality, portrayed vividly through Nyasha's actions. These states of society are also reflected in another statement made by Ngũgĩ's Wa Thiong'o in “The Language of African Literature: "English was the official vehicle and the magical formula to colonial elitedom" (439). Coincidentally, the word "magical formula" is reminiscent of Tambu's grandmother portraying the colonizer as "white wizards" they were able to control the lives of the native people. In relation to the colonizer's language as a sign of status, this is first displayed through Babamukuru in the novel, but also through Tambu's attempts to receive education and move away from her previous life.

Babamukuru and Maiguru both pursue higher degrees in England, the colonizer's country, and return in hopes of benefitting their families materially; Babamukuru takes this responsibility seriously, as he grasps firmly his hold as patriarchal head of the family, while Maiguru's achievements are disregarded—a fact Tambu realizes and later speaks of when referring to the gender discrimination of her culture. Babamukuru posits his own position of a patriarchal head of the family in a traditional format alongside that of the Western ideals prevalent in the mission where he teaches. Babamukuru does not return in the revolutionary role that Fanon calls for, but rather in the conservative fashion that believes the Westerner's culture will aid their own. When speaking of the goals of education in colonization Fanon states an effort was to "...turn its attention to the past of 
the colonized people and distorts it, disfigures it, and destroys it”, along with “...the final aim of colonization was to convince the indigenous population it would save them from darkness" (149). Babamukuru wants his family to adhere to traditional rules while on the Westernized mission, causing conflict with his daughter Nyasha and her open mindedness, characterized by dressing provocatively and reading controversial novels. This is Babamukuru in a position over the family in a more traditional format, acting patriarchally. Along with this, his education keeps him on the narrow track of thinking, despite being beneath the colonial oppression in various ways. Therefore, with Babamukuru it is obvious he is playing into the educated native that the colonizer wishes to have, without realizing his complicity in this system.

Babamukuru's immediate family benefits from this in their life on the mission, where we see Tambu in awe of the Western lifestyle, calling her first thoughts of his home a "palace", "mansion", and "castle" (85). It follows, then, that the family members will receive benefits as their father is the headmaster, and is described by Tambu when reflecting on Nyasha's possibilities to receive extra attempts at an exam, "The authorities thought Babamukuru was a good African. And it was generally believed that good Africans bred good African children who also thought about nothing except serving their communities. So Nyasha really didn't have to worry" (145). The essence of this is Tambu's recognition of the white mission personnel holding Babamukuru in a place of prestige, nevertheless saddled with the label of "African" in a derogatory format, and that his family is simply worthy of admiration due to being "bred" from this "good African" (145). However, before Tambu sees the violence that Babamukuru is capable of, she sees her uncle in a way that shines light upon his differences in returning from the colonizer's 
country, and his continual place in the colonizer's system: "He had pushed up from under the weight of the white man with no strong relative to help him. How had he done it? Having done it, what had he become? A deep valley cracked open. There was no bridge; at the bottom, spiked crags as sharp as spears. I felt separated forever from my uncle" (88). The focus on Babamukuru's family when they return to their native country from that of the colonizer depicts many of the irregularities that arise during the later periods of the colonial state.

Fanon says of the colonized intellectuals moving on from the conservative influences of Western culture, "Every colonized intellectual won over, every colonized intellectual who confesses, once he decides to revert to his old ways, not only represents a setback for the colonial enterprise, but also symbolizes the pointlessness and superficiality of the work accomplished" (158). Nyasha and Tambu's experience of education liberates them, as each character thinks more liberally about themselves as a colonized individual and a woman, disregarding the boundaries being placed around them by the colonizer and traditional culture. In Nyasha's case, she seems to refuse to adopt any of her culture back into her characteristics, and since she has spent much of her youth in England, she has lost this ability at such an impressionable age to connect to her original culture, though attempts are made through her discussions with Tambu and visits to Tambu's homestead. Instead, Nyasha is focusing on some of those values of the English culture, which are displayed in her actions of speaking back to her parents, reading of books outside of her supposed maturity level, and sneaking off for a cigarette in a rebellious fashion. Even other students at the school resent her, because "'She thinks she is white', they used to sneer, and that was as bad as a curse" (127). Tambu's reactions 
to these acts are what give the reader's the understanding of how different these are to the cultural values she has been a part of for so long, and now she is seeing evaporate away in her aunt and uncle's household. It is clear that Nyasha's choice to use English as her primary medium of communication is the foregoing of those other values of her culture, despite no longer living in England. Tambu's seems to see Nyasha, at times, as a proponent of the English culture, at least of an adolescent form, in the previously mentioned actions.

One conversation that takes place between Tambu and Nyasha in their shared bedroom relates to Nyasha and her family's return from England, and the reverse culture shock she felt upon attempting to assimilate into her previous life. This allowed her to have a recognition of her maturation in England, and the effect it's had on her persona, along with the problem it caused within her family. Speaking to Tambu, Nyasha refers to herself and her brother as "hybrids" and that their parents “...don't like it at all” (107). Nyasha understands the position she is placed within her family, especially in relation to her father, who expects her to act in an obedient format towards him. Nyasha portrays these feelings in a revealing moment of her place within her family, "I can't help having been there and grown into the me that has been there. But it offends them-I offend them. Really, it's very difficult." (107). Nyasha's comprehension of her place within her family proves that she will continue towards the woman she is becoming, but the awareness of this strife weighs upon her throughout the text.

Fanon describes the colonized intellectual's hopes of moving past their current level of oppression with certain vigor they possess, and this spirit aids them in the task of reclaiming their identities in the face of their people, the colonizer, and the world. This 
task of pursuing into themselves and their identity is perilous; pushing past their current state of oppressed baseness in attempts to connect to a different past, one not tainted by the colonizer's hand (148). This attempt by the colonized intellectual brings about a change of psychological importance, “...the colonized intellectual has thrown himself headlong into Western culture. Like adopted children who only stop investigating their new family environment once their psyche has formed a minimum core of reassurance, the colonized intellectual will endeavor to make European culture his own" (Fanon 156).

Nyasha spent time in Britain as a young child, reflecting the "adopted children" phrase, and her assimilation of the culture is similar to a psyche that has been created in the colonizer's environment. Nyasha, an intellectual “... who has slipped into Western civilization through a cultural back door..." finds herself unable to tear from these modes, and her assimilation of this culture allows her to see what is being done to her culture and people, her family, and her inability to change this becomes too much for her to bear (Fanon 156). Tambu views the tensions boil between Babamukuru and Nyashaone patriarchal and conservative and the other idealist - clashing in uncontrollable eruptions, and as Fanon says about this controversial stage of the intellectual: “...for lack of a cultural stimulus comparable to the glorious panorama flaunted by the colonizer, the colonized intellectual frequently lapses into heated arguments and develops a psychology dominated by an exaggerated sensibility, sensitivity, and susceptibility" (Fanon 157). This defensiveness by Nyasha of the Westernized ideals she acquired conflicts directly with Babamukuru's first stage colonized intellectual attempts of adhering to patriarchal rule through both traditional and Western formats. 
These episodes between Babamukuru and Nyasha reach an explosive point one evening after a local dance, as she returns later than Chido or Tambu and is accused by Babamukuru of acting like a "whore" (154). This terrifying and graphic scene spirals out of control as Babamukuru and Nyasha fight, with the former threatening to kill Nyasha for her defiance. Chido and Maiguru must intervene to stop the violence, pleading for Babamukuru to cease and despite their physical restraint of Babamukuru, he still spits into Nyasha's face and disowns her (154-7). After Nyasha leaves the house to smoke and Tambu joins her, Tambu begins a mediation upon the horrendous actions of her uncle, that leads her to questioning men's role in this system of patriarchal oppression that seems to continuously foster violence, even with, “...heroes like Babamukuru...” (157). This is a defining realization to the roles of masculine and feminine, as Tambu realizes that this violence cares not for education, class, or racial levels, "But what I didn't like was the way all the conflicts came back to this question of femaleness. Femaleness as opposed and inferior to maleness" (157).

Nyasha continues defying Babamukuru, as she recognizes her inability to live any other way, "I guess he's right, right to dislike me. It's not his fault, it's me. But I can't help it. Really, I can't. He makes me so angry. I can't just shut up when he puts on his God act. I'm just not made that way. Why not? Why can't I just take it like everybody else does? I ought to take it, but really, I can't'" (255). Nyasha is the first to recognize Babamukuru's complicity in the colonized system, and in a later scene of distress that arises from the conflict between his conservative and her progressive ideals she comments on her father, "'They put him through it all. But it's not his fault, he's good.' Her voice took on a Rhodesian accent. 'He's a good boy, a good munt. A bloody good 
kaffir,' she informed in sneering sarcastic tones" (269). Nyasha's ability to come to this conclusion is from her assimilation in the second stage format of the colonized intellectual, and attempting to become one of the colonizer's, which gave her the insight to her father's condition, but results in her mental breakdown. Beginning with throwing pots and ripping books with her teeth, Nyasha continues to say, “'They've trapped us. They've trapped us"', then after exhausting herself in her rage tells her father, "'I don't hate you, Daddy,' she said softly. 'They want me to, but I won't'” (269). The scene culminates in Nyasha speaking quietly to her mother, "'Look what they've done to us,' she said softly. 'I'm not one of them but I'm not one of you'” (269). Much like Babamukuru is incapable of moving past the modes of power he receives from either culture, Nyasha is incapable of reconnecting to her native culture and becomes lost in a space between colonizer and colonized, contentious with either and unable to connect to those around her.

Tambu begins from a state of poverty, requiring her to recognize her roots as she moves forward and as Fanon says, "If we want to respond to the expectations of our peoples, we must look elsewhere besides Europe" (239). The act of the women becoming educated and more progressive is the most radical act of the education of the colonized, as these women are able to step from beneath that double layered shroud cast by the patriarchal cultural systems and the colonizer's imposing institutions. It allows the culture, where previously women were not allowed but certain tasks, to adapt and evolve, further towards that intellectual Fanon describes. As Tambu is the protagonist in this novel, we see this mostly portrayed in her own obstacles; yet, this is a struggle continuously faced by all of the women in the text, as they must rely on the men to aid 
their advancement, despite the women's own merits. Tambu's mother, during a speech on womanhood, depicts their placement perfectly, "'And these days it is worse, with the poverty of blackness on one side and the weight of womanhood on the other. Aiwa! What will help you, my child, is to learn to carry your burdens with strength" (15). This comes as the first of many reminders to Tambu's position as a young woman, and a warning to not deviate from her predestined path. As Tambu narrates her family's lives, she relates that, "The needs and sensibilities of the women in my family were not considered a priority, or even legitimate", which requires her to push against those gender discriminations, despite her young age (20).

Nevertheless, Tambu's experiences with this begin early, during her continued attempts to receive education and the ways in which her mother, father, and brother doubt her abilities. Her brother is offered to live with her Uncle Babamukuru at the mission to receive education, due to his position as the only son. She is continuously lectured on her role as a woman by her father, despite his renown incompetence within the family and lack of self-control: "'Can you cook books and feed them to your husband? Stay at home with your mother. Learn to cook and clean. Grow vegetables"” (24). Yet, Tambu's answer to this is exactly as her father wishes: with a small allotment of seed from her family, she grows maize to sell and pay for her education (36). Not only is she taunted by her father and warned by her mother, doomed to failure in both of their eyes, but when she does succeed, her father attempts to take the money from her because she is his daughter. This comes after a local teacher takes her to the city to market her corn, and after an interesting altercation with white Rhodesians, she is given a substantial sum for her means and it is deposited for her education (43). 
Language arises as a key factor again, as Tambu experiences from Nyasha and Chido an incapability for Shona in favor of English, such as when her brother Nhamo returns from his schooling at the mission; however, Nhamo explicitly chooses to disregard Shona when he pleases, feigning the ability to comprehend the language due to his immersion in English at the mission. This is praised by their father, as he says, “... it was the first step in the family's emancipation since we could all improve our language by practicing on Nhamo" (72-73). Though, before this, when Tambu attempts to learn on her own, she is continuously met with opposition: "He thought I was emulating my brother, that the things I read would fill my mind with impractical ideas, making me quite useless for the real tasks of feminine living" (48). This assertion is simply one of many gender discriminations she faces by her father as he continues to push her towards the path of a traditional woman within their culture.

After her brother Nhamo's death, she receives the opportunity to proceed to the mission and live with her uncle's family, and receive an education. Whereas the male members of the family, worried about the place of not only losing a male but the possibility of Tambu later marrying into another family, see her education as taking her skills elsewhere. In a family meeting, Tambu's father Jeremiah displays unease in her education once more, "Tambudzai's sharpness with her books is no use because in the end it will benefit strangers"” (77). This remark, just like many of the other issues Tambu faces with her family, comes only due to her gender and the function her father and mother attempted to implement upon her beforehand. Regardless of these views, and the seemingly coincidental act that allowed her this opportunity, Tambu's intellect and drive helped her prevail, for it was her cultivation of maize that led to her initial schooling and 
the possibility to carry on further with her studies. Therefore, it comes as no surprise that she refers to the time period of moving to the mission as “...the period of my reincarnation" (125).

During the education process, one of the notable changes that occur are the switches in language, moving from the mother tongue of Shona to English. Also, when referring to the white people she encountered at the mission, Tambu relates their reluctance to speak in English and rather converse with her in Shona. Tambu found this difficult because she hoped to further develop her English, but also “...we had developed a kind of reflex which made us speak English when we spoke to white skins and reserved our own language for talking to each other" (141). This is intriguing for two points; first, it is that she refers to these white people as "white skins", which signifies some disassociation from her daily activities and very little contact, whereas if she engaged with them often they would likely appear as characters with names (141). Secondly, is how Tambu states that Shona, their native language, they speak only with one anotherpointing to Tambu's continued respect and use for her traditional language, unlike her deceased brother and cousins who attempted to speak in English exclusively.

Much like the tale her grandmother tells her of the family history, the traditional language of Shona captures history, such as Ngũgĩ's Wa Thiong'o discusses in “The Language of African Literature", where he argues that the utilization of the traditional languages by the colonized ensured their continued use: "These languages, these national heritages of Africa, were kept alive by the peasantry" (Thiong'o 447). This portrays how the colonized peasantry carry history through their language, and the fantastical way in which this is retold to Tambu is similar to those oral histories of this native language and 
tradition. This connection to the past via the Shona language is an important trait for Tambu, as there is not only much reflection on this during her initial schooling and transitioning to English, but also during her path of becoming a colonized intellectual who still respects and reveres traditions of her culture.

During her time at the mission, Tambu grows as a young woman and intellectual, and the experiences in her uncle's household are prevalent in this process. This growth results in independent acts by Tambu, much like those of her cousin Nyasha. Due to an image issue of Tambu's parents being unmarried, Babamukuru decides to stage a wedding to formally unite the two, enacting his power as head of the family and requiring Tambu's mother and the other women to carry out this ritual granting further patriarchal control (224-5). Here Tambu defies Babamukuru, refusing to attend the wedding and resulting in her being accused of being spoiled by the "good life" (224). She then receives a form of counseling by Babamukuru, as he tells her she was previously held up as an example for Nyasha follow, but no longer as she has disobeyed him, and Tambu receives two weeks of household chores as punishment (227). In one format, the control of Tambu relates to Fanon's discussion of occupation, "Sooner or later, however, the colonized intellectual realized that the existence of a nation is not proved by culture, but in the people's struggle against the forces of occupation." (159) For Tambu, this occupation is both the colonizer and the male dominated sectors of her culture which suppress her, as she rises against both forms of oppression in her path.

Fanon often discusses the colonized intellectual's fear of losing themselves, but in Tambu, it is not that she believes she will lose herself, but rather never become herself. "Fully aware they are in the process of losing themselves, and consequently of being lost 
to their people, these men work away with raging heart and furious mind to renew contact with their people's oldest, inner essence, the farthest removed from colonial times." (148). She works with "raging heart and furious mind" once given the opportunity for education at home and the mission to continue forward. Her contact with people is through her memories of the poverty they face, and her grandmother's story of her Uncle Babamukuru's path, who relied on the "white wizards" for help, shortly after they put them in a state of poverty by casting their family from a farm. She recognizes what her path as a woman in poverty would be, as she sees the women in her family waiting for whatever opportunities Babamukuru offers.

Even when Tambu is rewarded a scholarship to proceed to a convent for further education, Babamukuru is hesitant to allow her to go, or rather, relinquish control over her. Despite Tambu's educational achievements paving the way for this scholarship, her achievements are given to Babamukuru, as he is congratulated by the family "... on having moulded [sic] my mind so skilfully [sic] that even white people were impressed by the result..." (244). Yet, Babamukuru eventually recognized the benefits to Tambu's opportunity and grants permission, which Tambu defines as, "I was to take another step upwards in the direction of my freedom" (246). Though she has to receive male permission to proceed further on her path, Tambu's accomplishments from her discipline and voracious drive for excellence supplied these opportunities for success.

Babamukuru and Nyasha display the mental effects of colonization as they struggle with their unsustainable roles in this system: "Let us decide not to imitate Europe and let us tense our muscles and our brains in a new direction. Let us endeavor to invent a man in full, something which Europe has been incapable of achieving" (236). Tambu 
doesn't imitate the Europeans such as Nyasha does, but rather utilizes the European-style education she receives to continue defining herself and pushing further towards her goals. The imitation that Nyasha carries out is incapable of being continued, as Nyasha breaks down due to her attempt at becoming something she was adopted into during her time in Britain. It is during this attempt at imitation her psyche recognized many of the colonizer's aims, specifically through herself, her father, and her mother. As far as Babamukuru, Tambu saw the violence he is capable of towards Nyasha, despite Tambu's previous beliefs that Babamukuru was the family's savior. As Tambu says of her uncle when first moving to the mission, "Babamukuru was God, therefore I had arrived in Heaven. I was in danger of becoming an angel, or at the very least a saint, and forgetting how ordinary humans existed - from minute to minute and from hand to mouth" (95). This description by Tambu identifies Babamukuru's decision to ignore all facets of their culture, and only focusing on those which granted patriarchal authority.

Neither Babamukuru or Nyasha are sustainable options for this life, as displayed by their reluctance and inabilities for progressing with an adequate blend of both Western and traditional cultures. Meanwhile, Tambu is on course to become what Fanon speaks of in his conclusion, "For Europe, for ourselves and for humanity, comrades, we must make a new start, develop a new way of thinking, and endeavor to create a new man” (239). Tambu's innate desire to transform her life pushes her to unconsciously seek to create a new postcolonial woman; a powerful citizen who will embody the transcendence of knowledge and culture Fanon speaks of, as the most progressive possibility of rising from the colonized position is the woman taking off from her humble conditions and receiving the respect both she, and her gender, deserve. 


\section{Works Cited}

Dangarembga, Tsitsi. Nervous Conditions and Related Readings. The Women's

Press Ltd., 1988.

Fanon, Frantz. The Wretched of the Earth. 1963. Présence Africaine.

Osadebay, Dennis. "Young Africa's Plea", Nervous Conditions and Related

Readings. The Women's Press Ltd., 1988.

Wa Thiong’o, Ngũgĩ. “The Language of African Literature.” Colonial Discourse:

Post-Colonial Theory, edited by Patrick Williams and Laura Cluismau, Columbia

University Press, 1994, 435-455. 